\title{
NEW COLLEMBOLA FROM PUERTO RICO
}

\section{David L. Wray ${ }^{1}$ \\ INTRODUCTION}

The following are some forms of Collembola that have been collected in various regions of Puerto Rico, those appearing new to science being described herein. I wish to thank Professor J. Maldonado Capriles for his kindness in sending me this material for study. It is interesting to find some forms very close to those described by Schött in 1893 from Africa and also some close to those figured by Imms from India.

\section{FORMS OF COLLEMBOLA FOUND IN PUERTO RICO}

\section{Genus Dicranocentrus Schött, 1893}

Genotype: Dicranocentrus gracilis, Schött, 1893, Bihang. Till K. Svenska Vet.-Akad. Handlinger Band 19. Afd. IV. No. 2, pp. 21-23, Taf. VII, figs. $1-5$.

In 1893, H. Schött erected the Genus Dicranocentrus to receive a new species gracilis that he studied from Kamerun. He had two specimens from which to draw his description. His generic description needs amendment only because he recognized four antennal segments in his specimens. Since then Salmon (1951) placed this genus in the Brchesellini, and mentioned the six segmented antennae. The one species that I describe below falls within this genus, but differs in certain characters to such an extent that I hesitate to place it finally therein, so have erected the following new subgenus, using Schött's Dicranocentrus gracilis as the subgenotype of Dicranocentrus s. str., and my new form Dicranocentrella marias as the subgenotype for the new subgenus.

Subgenus Dicranocentrus s. str.

Subgenotype: Dicranocentrus gracilis, Schött

Orcheselline in general body appearance, fourth abdominal segment not over $1 \frac{1}{2}$ times the third. Mesonotum not prominent. Antennae 6segmented, third segment indistinctly separated from fourth. Scales present. Eyes not studied. Dentes with longitudinal rows of spines. Mucro with two teeth and a basal spine.

\section{Subgenus Dicranocentrella new}

Subgenotype: Dicranocentrella marias, n. sp.

Orcheselline in general body appearance, with fourth abdominal segment

${ }^{1}$ Entomologist, Department of Agriculture of North Carolina, Raleigh, N. C. 
not much longer than the third. Antennae 6-segmented, third segment not distinctly separated from fourth, fifth, and sixth annulated. Antennae longer than body and head combined. Scales present. Eyes 16, 8 on each side of head. Dentes with several longitudinal rows of stout spines on proximal half. Mucro with two teeth and a basal spine. This subgenus differs from Dicranocentrus Schött in the length of the antennae and the position of the longitudinal rows of dental spines.

\section{Dicranocentrella marias, n. sp.}

Length up to $2.25 \mathrm{~mm}$. Background color yellow with a diffusion of purplish pigment scattered over the head and body, heavier on head and lateral margins of thorax. Legs heavily pigmented throughout. Traces of pigment on manubrium. Antennal segments purplish, lighter at joints. Eyespots heavy purple. A dark spot in middle of front of head. Orcheselline in general appearance (fig. 1, Q), the fourth abdominal segment not more than $1 \frac{1}{2}$ times the third. Antennae 6-segmented, very long, as long as head and body combined. Third segment indistinctly separated from the fourth (fig. 1, S). Proportions of segments as 15:40:25:50:185:85. First four segments heavily scaled; fifth and sixth annulated. Head, body, and legs heavily scaled. Scales on manubrium and ventrally on dentes. Scales with rounded apices (fig. 1, V). Rami of tenaculum quadridentate. Unguis (fig. 1, U) with outer teeth and with one tooth on inner margin on distal half. Unguiculus unarmed, lanceolate. One unknobbed tenent hair on each tibiotarsus subequal in length to unguis. Hind legs long. Furcula about as long as hind legs. Proportions of manubrium to dentes as 20:38. Dentes with two or three longitudinal rows of stout simple spines situated on proximal third, and with a row of stout curved setae along lateral margins (fig. 1, T). Ventrally, heavily clothed with long scales. Dentes with a basal transverse row of stout setae. Mucro (fig. 1, R) with a long upcurved apical tooth, a stout proximal tooth, and a basal spine. Dentes become very narrow and slender toward apex, the deep dorsal crenulations end about 6 or 7 mucro-lengths from apex. Clothing of thickly set brownish scales, short and longer, much stouter, fringed setae.

Type locality: Las Marias, P.R., $5 \mathrm{~km}$. from town at 500 -foot altitude, August 21, 1951. Many specimens taken in litter by J. Maldonado Capriles. Maricao, August 28, 1951, Road 27, 400-foot elevation, J. M. Capriles.

\section{Genus Dicranocentruga, new}

Paronelloid in general appearance. Fourth abdominal segment long, about half as long as body. Mesonotum not prominent. Furcula long, very slightly diminishing in width throughout its length. Manubrium longer than dentes. Dentes with at least two longitudinal rows of stout spines. 


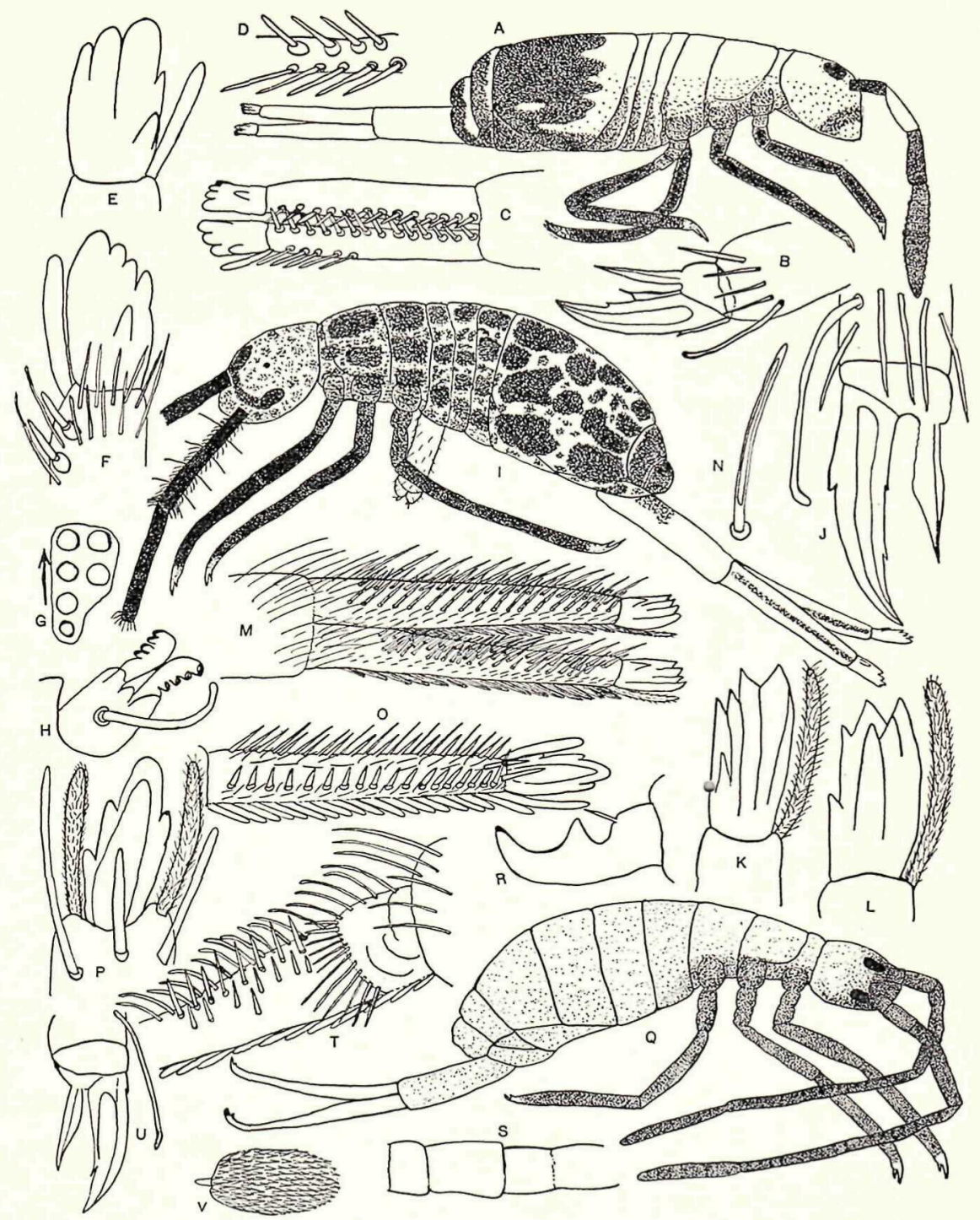

Fig. 1.-A-H, Dicranocentrus jataca, n.sp.: A, Whole animal; B, foot, showing unguis and unguiculus; $\mathrm{C}$, dentes-mucro, showing dental spines; $\mathrm{D}$, dental spines; E, mucro; F, mucro; G, eye-patch; H, tenaculum. I-P, Dicranocentropha sabana, n.sp.: I, Whole animal; J, foot, showing unguis and unguiculus; $\mathrm{K}-\mathrm{L}$, mucro; $\mathrm{M}$, dentes-mucro; $\mathrm{N}$, seta from dens; $\mathrm{O}$, dens with arrangement of dental spines; $\mathrm{P}$, mucro. Q-V, Dicrano-centrella marias, n.sp.: Q, Whole animal; R, mucro; S, first four antennal joints; $T$, dental spine arrangement; $U$, foot, showing unguis and unguiculus $\mathrm{V}$, scale. 
Scales present. Mucro paronelloid, with four or five apical teeth, and a basal tooth. Eyes 12, 6 on each side of head in 2 parallel rows. Antennae 4 -segmented, of normal length, last segment annulated.

Genotype: Dicranocentruga jataca, n. sp.

\section{Dicranocentruga jataca, n. sp.}

Length up to $1.5 \mathrm{~mm}$. Background color yellow with blue pigment, chiefly along lateral margins of body (fig. 1, A). Antennae blue throughout. Traces of blue pigment on head; pigment laterally from mesothorax to abdominal segment 4 . Coxae and legs blue; abdominal segment 4 blue laterally, ventrally, and a broad posterior band dorsally; abdominal segments 5 and 6 laterally blue. Furcula yellow, but spines give the dentes a brownish tinge. Antennae 4-segmented, 11/2 times longer than head or in proportion of $35: 20$. Proportions of antennal segments as $30: 40: 40: 60$, last segment annulated. Unguis (fig. 1, B) stout, with large lateral teeth, well-developed paramedian teeth, and a pair of teeth on distal third of inner margin. Unguiculus lanceolate, two-thirds length of unguis. Eyes 12,6 on each side of head, in 2 parallel rows (fig. 1, G). Abdominal segment 4 about six times the length of abdominal segment 3 . Tenaculum rami 4-dentate, corpus with one large bent seta (fig. 1, H). Furcula long, about two-thirds as long as body, or in proportion of 45:60. Proportions of manubrium to dens to mucro as 115:100:10. Manubrium with many dorsal setae, longer near apex. Dentes with two rows of dorsal stout spines, one row situated on inner margin and the other on lateral or outer margin, about 18 or 19 in inner row, 15 or 16 in outer row; with several rows of stiff short hairs alongside rows of spines; also longer stiff setae among the spines; ventrally, dentes are thickly set with narrow long scales rounded apically. Mucro paronelloid in shape, truncate apically, with four or five apical teeth and a large subbasal one; the number of teeth varies from three apical and one basal to five apical and one basal. Apex of dens with long large fringed setae or processes originating near base of mucro.

Superficially, the body fascies appear very similar to those of any Entomobrya, but for the long paronelloid furcula which places it in the subfamily Paronellinae. This genus is very near the genus Trichorypha Schött (1893), in that Dicranocentruga has the manubrium longer than dentes, 12 eyes are present, the mucro is similar, and the unguis has welldeveloped paramedian teeth. It differs from Trichorypha, however, in the length of antennae, the unguiculus is unarmed, and the scalelike lobe at the apex of the dens is absent. It is very near Dicranocentroides.

Type locality: Quebradillas, Guajataca, P.R. Taken July 4, 1951 by J. Maldonado Capriles; also by the same in Maricao, August 28, 1951. 


\section{Genus Dicranocentroides Imms, 1912}

This genus similar to the one above is also placed in the subfamily Paronellinae Börner (1906) of the family Entomobryidae.

Genotype: Dicranocentroides fasciculatus Imms, Proc. Zool. Soc. London, Mch. 1912.

Subgenus Dicranocentroides (Dicranocentroides) s. str.

Paronelloid in general appearance. Scales present. Mesonotum not prominent. Antennae long, about half as long as the body; 4-segmented, with first segment well-developed and as long as the second. Fourth abdominal segment long, about half as long as body. Furcula long, diminishing in diameter but little throughout its entire length. Dentes with a longitudinal row of short stout spines. Mucrones with two large terminal teeth, two dorsal, subapical, and a large lateral tooth. Eyes 16,8 on each side of head. Postantennal organ absent.

Subgenotype: Dicranocentroides fasciculatus Imms, 1912.

\section{Subgenus Dicranocentropha new}

Subgenotype: Dicranocentropha sabana, n. sp.

This subgenus is represented in the Puerto Rican material by one species which varies somewhat from Imms' typical form, Dicranocentroides ( $D i$ cranocentroides) s. str. I have therefore erected a new subgenus, since it is so closely related to the above. It is paronelloid in general fascies. Scales present. Antennae long, much longer than for Imms' form, the first joint being alone longer than the head, the second and third about equal to first, the fourth a little longer than the others, total length of antennae as long as or slightly longer than body. The furcula is nearly as long as the body, legs about as long as furcula, and there are several longitudinal rows of stout spines on dentes instead of one as given by Imms for his $D$. fasciculatus, 1912.

\section{Dicranocentropha sabana, n. sp.}

Length up to $2.25 \mathrm{~mm}$. Yellow background color on which is dispersed bluish-purple pigment in the form of splotches, spots, and bands over head and body (fig. 1, I). Antennae and legs deep purple with pigment solidly distributed. Head with purplish pigment sparsely distributed in specks and spots; a dark line runs between eyespots along bases of antennae; a small dark spot in vertex. Eyespots dark. Ventral tube yellow. Base of manubrium with a splotch of purplish pigment and with a line of purple along middle of dentes. A broken band across dorsum, and a large splotch posteriorly and laterally on abdominal segment 4; pigment laterally along head and body, abdominal segments 5 and 6 with splotches 
of pigment. Paronelloid in general appearance. Fourth abdominal segment long or about $4 \frac{1}{2}$ times as long as the third, or as $45: 10$. Antennae long or about as long as body, first segment slightly longer than head, or as 45:35; first three segments about equal, fourth slightly longer than the others. Eyes, eight on each side on dark patches. Postantennal organ absent. Legs very long, the third pair reaching to end of abdomen; the tibiotarsi, very long or as long as manubrium. Unguis (fig. 1, J) with lateral teeth and two teeth on inner margin, one a third from the base, the other a third from the apex. Unguiculus lanceolate, acuminate, two-thirds the length of the unguis. Tenent hair one on each foot, subequal in length to unguis, unknobbed. Ventral tube long, apical vesicles bilobed. Furcula very long, reaching to metathorax. Proportions of manubrium to dentes to mucrones as 40:50:4. Dentes taper but little from base to apex. Dentes with several rows of short and long heavy spines and with short stiff hairs (fig. 1, 0). Ventrally with close set long scales. Mucro, suboblong, with four apical and two subapical teeth and a basal tooth. Body with short and long hairs, and with scales. Antennae with short and long hairs. Legs heavily clothed with thickly set hairs.

Type locality: Quebradillas, Guajataca, P.R., July 4, 1951, J. Maldonado Capriles; also by the same in Maricao, August 28, 1951.

\section{Genus Lepidocyrtus Bourlet, 1839}

\section{Lepidocyrtus caprilesii, n.sp.}

Length up to $1 \mathrm{~mm}$. Background color yellowish-white, the heavy layer of scales gives the body and head a deep brownish tinge wherever thickest. A deep purple marginal line along ventrolateral edge of mesothorax just above coxae and another purple marginal line along lower edge of mesonotum; these lines are interrupted and form large purple splotches in the same position on metathorax (fig. 2, A). A few small purple spots laterally on first three abdominal segments. Abdominal segment 4 with two large patches of purple on anterior margin and two about on the middle of lateral margin; both of these in same position as those on metathorax. Head with black eyespots, a midspot on vertex, and traces of purple laterally and on bases of antennae. Antennae with traces of purple and a purple band distally on the second segment. Legs yellow except for weak traces of pigment, becoming heavier on tibiotarsi. Venter of body and furcula yellow. Antennae much longer than head, antennal segments 1 and 2 about equal in length, and combined, as long as the head. Apical end of antennal segments with a thickly set, straight row of setae (fig. 2, E-F). Eyes eight on each side. Body heavily clothed with deep brownish scales, which are rounded apically, heavily ribbed (fig. 2, B). Unguis (fig. 2, C) with two outer teeth and two pairs of inner teeth. Unguiculus 


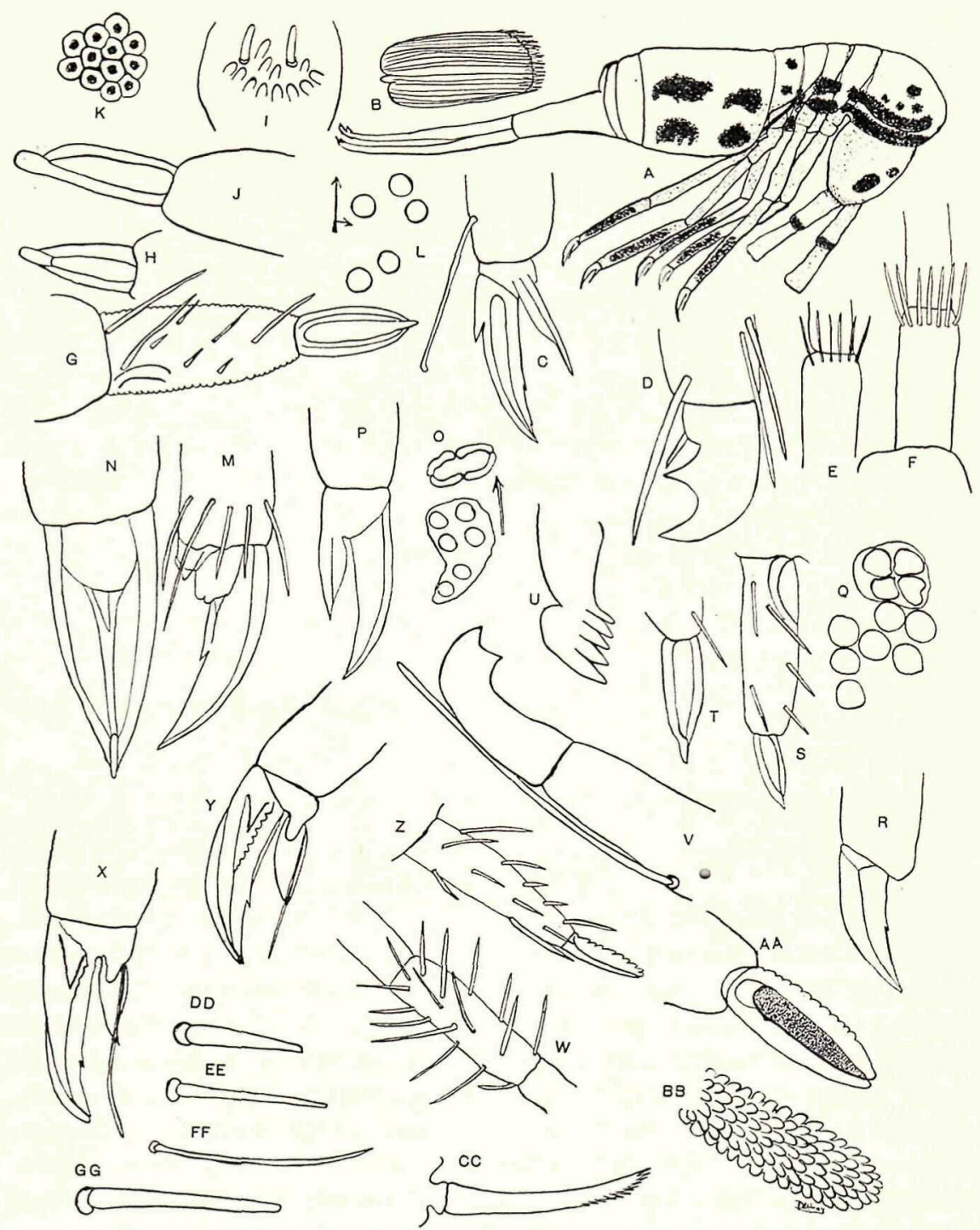

Frg. 2.-A-F, Lepidocyrtus caprilesi, n.sp.: A, Whole animal; B, scale; C, foot, showing arrangement of unguis and unguiculus; $\mathrm{D}$, mucro. $\mathrm{E}-\mathrm{F}$, setae arrangement on antennal joint. G-N, Portachorutes mambatus, n.sp.: G, Dens-mucro; H, mucro; I, organ of third antennal segment; J, mucro; $K$, integument; $L$, eyes. $M-N$, views of unguis. O-P, Folsomia sylvia, n.sp.: O, Eyes and postantennal organ; P, foot. Q-U, Brachystomella agrosa, n.sp.: Q, Eyes and postantennal organ, R, foot; S, dens-mucro; T, mucro; U, apex of maxilla. V, Pseudosinella subfusa, n.sp., mucro. W-GG, Sphyrotheca aleta, n.sp.: W, Setae of third antennal segment; X, front foot; Y, hind foot; $Z$, dens-mucro; $A A$, mucro; $B B$, ventral tube apex; $C C$, anal appendage; DD, form of setae between eyes and back of head; EE, form of blunt setae on dorsum of abdomen and posterior of head; FF, form of setae on body; GG, form of large blunt setae on body. 
lanceolate, acuminate, untoothed, about four-fifths as long as the unguis. Tenent hair subequal to unguis. Mesonotum strongly projecting over head. Fourth abdominal segment five to six times as long as third. Furcula extends as far as ventral tube. Dorsal crenulations of dens extend to about 3 mucro-lengths from end of dens. Mucro (fig. 2, D) rather long, with apical and anteapical teeth equal in size, basal spine present, stout. Body clothed with rather long closely appressed and reclinate setae especially thick on antennae, legs, and posterior of body.

Type locality: Las Marias, P.R., $5 \mathrm{~km}$. from town, 500 -foot elevation, August 21, 1951, in litter, collected by J. Maldonado Capriles.

\section{Genus Portachorutes new}

Genotype: Portachorutes mambatus, n. sp.

This genus is closely related to Pseudachorutes in general body fascies, but differs in that the postantennal organ is absent and the eyes number five. Antennae, 4-segmented, subequal to head in length. Furcula short, but with well-developed dentes and mucro. Unguis present, unguiculus absent or tuberculate. Body integument reticulate. Pigment dispersed in nucleated specks over body.

\section{Portachorutes mambatus, n. sp.}

Length up to $2 \mathrm{~mm}$. Background color yellow with purple pigment dispersed over the body in the form of nucleated specks (fig. 2, K). Venter more lightly pigmented. Pigment on dentes and manubrium, with traces of purple on coxae, precoxae, and femorae. Antennae subequal to head in length; proportions of segments as 25:25:25:30. Organ of third antennal segment consists of several sense rods in a field (fig. 2, I). Several large sensory setae on fourth antennal segment. Eyes five on each side of head (fig. 2, L). Postantennal organ absent. Unguis (fig. 2, M-N) curved, stout, and with a weak inner tooth which may be absent on some feet. Unguiculus absent, represented by a mere tuberculation. Tenent hairs absent. Ends of tibiotarsi striated. Rami of tenaculum tridentate. Furcula short, about as long as hind tibiotarsus and unguis combined. Proportions of manubrium to dentes to mucro as 20:25:13. Dens with two long basal, dorsal setae and five or six shorter setae dorsally (fig. 2, G). Mucro (fig. 2, H) with dorsal lamellae ending before apex of mucro. Apex of mucro bluntly rounded and nearly straight.

Type locality: Las Marias, P.R. This form was taken from litter $5 \mathrm{~km}$. from town, at 500-foot elevation, August 21, 1951, by J. Maldonado Capriles.

This form superficially resembles Pseudachorutes in general structures, but I can find only five eyes on each side and the postantennal organ is 
absent. The organ of the third antennal segment is different from that of closely related forms.

Genus Isotoma Bourlet, 1839

Isotoma minor Schäffer, 1896

One specimen of this easily recognized species was taken at Maricao, P.R., August 28, 1951, on Road 27, 400-foot elevation, by J. Maldonado Capriles.

\section{Genus Folsomia Willem, 1902}

Folsomia sylvia, n. sp.

Length up to $1 \mathrm{~mm}$. Color white, except for bluish pigment laterally on thorax, traces on coxae, and femorae, and slightly on antennae. Head more heavily bluish, with pigment dispersed in specks and splotches all over; eyespots heavily purplish and with pigment between these and antennal bases. Eyes 12, 6 on each side (fig. 2, O). Antennae subequal to head in length, proportions of segments as $8: 10: 12: 25$, fourth antennal segment with terminal knob; organ of third segment consists of two small sense rods. Postantennal organ broadly elliptical, notched in middle on both sides, 3 to 4 times diameter of eye in length (fig. 2, O). Unguis (fig. 2, P) curved, unarmed; unguiculus unarmed, acuminate, half the unguis in length. Furcula short, reaching only to posterior edge of abdominal segment 3; dentes twice as long as manubrium, mucro 2-toothed. Rami of tenaculum 4-dentate, corpus with one stout seta. Tenent hairs absent. Body clothed with numerous short stiff hairs and among these are many longer, stouter, setae on posterior of body.

This species is distinguished from North American species by the shape of the post-antennal organ and number of eyes.

Type locality: Las Marias, P.R., $5 \mathrm{~km}$. from town, 500-foot elevation, August 21, 1951, taken in litter by J. Maldonado Capriles.

\section{Genus Brachystomella Ågren, 1903}

Brachystomella agrosa, n. sp.

Length up to $1 \mathrm{~mm}$. Yellow background color over which purple pigment is dispersed in splotches and spots, (somewhat marbled), over head, antennae, and body. Legs more lightly pigmented. Eyes (fig. 2, Q) eight on each side on black spots. Postantennal organ of four tubercles which are almost as large as adjacent eye. Antennae shorter than head; the fourth segment with several olfactory setae and a trilobed terminal sense club. Mandibles absent. Maxillae have five or six terminal teeth (fig. 2, U). Unguis (fig. 2, R) short, stout, and with one inner tooth. Tenent hairs 
absent. Rami of tenaculum tridentate. Mucrones (fig. 2, S, T) one-third of dentes in length, boat-shaped, ending in an upturned blunt apex. Anal horns absent. Clothing consisting of sparse slender, long, curved setae dispersed over head and body. Antennae thickly set with long slender setae.

Type locality: Guanica, P.R., November 20, 1951, in litter, collected by J. Maldonado Capriles.

\section{Genus Pseudosinella Schäffer, 1897}

\section{Pseudosinella subfusa, n. sp.}

Length up to $0.8 \mathrm{~mm}$. Yellowish-white background with blue pigment diffused all over head and body in the form of small specks. Eyes two on each side of head on a small irregularly shaped dark patch. Antennae slightly longer than head. The fourth abdominal segment about two times the length of the third. Unguis has a pair of lateral teeth, a pair of prominent paramedian teeth which are not opposite, and only one inner tooth discernable. Unguiculus, straight, lanceolate, about two-thirds the length of the unguis. Tenent hair reduced, minute, short. Dentes $1 \frac{1}{2}$ times the manubrium in length. Dentes and manubrium have scales ventrally and many long curved hairs dorsally. Mucro, (fig. 2, V) slender, upcurved, with two apical teeth of equal size but not as deeply cleft as usual in this genus; a basal spine was not observed, but a long seta was present which originated on apical third of dens and extended beyond apex of mucro.

This species is close to $P$. alba Packard in possessing only two eyes on each side of the head, but its color, shape of mucro, and smaller size distinguish it from that species.

Type locality: Maricao, P.R., August 28, 1951, taken on Road 27, at 400-foot altitude, by J. Maldonado Capriles.

\section{Genus Sphyrotheca Börner, 1906}

\section{Sphyrotheca aleta, n. sp.}

Length up to $1 \mathrm{~mm}$. General coloration consists of purple pigment diffused over a yellowish background over entire body. Antennae purple throughout, head and body splotched and marbled with purple, but with lighter areas showing through, legs purple throughout down to claws, manubrium and dentes with purplish pigment, and mucro purple in central part. Eyes eight on each side, on black eyespots. Ventral tube strongly tuberculate (fig. 2, BB), unpigmented, Antennae longer than head, or as 185:95; proportions of segments as 15:25:45:100. Fourth antennal segment subdivided with eight subsegments, besides basal and apical joints, and about 10 whorls of hairs. Long setae of third segment not con- 
fined to one end, but distributed throughout (fig. 2, W). Unguis (fig. 2, X) with a tunica and with one tooth on inner margin one-third the distance from apex, weakly pseudonchiate at base, with lateral teeth and an outer tooth. Unguiculus broadly lamellate, with one inner tooth, and terminating in a spinnate filament which extends beyond apex of unguis on front feet, but is only subequal in length to unguis on last two pairs of legs (fig. 2, Y). Proportions of manubrium to dentes to mucro as $37: 62: 18$. Dentes with several dorsal setae, some much longer, outstanding (fig. 2, Z). Mucro (fig. 2, AA) spoon-shaped, with crenulations on inner margin, entirely smooth on outer margin. Ventral tube very long, heavily tuberculate. Clothing of long curving pointed setae, large spinelike setae truncate at apex; those between eyes being short and stubby, those on body much longer and stouter, but straight (fig. 2, DD-GG). Anal appendage (fig. 2, CC) stout, curved, ciliated apically.

Type locality: Quebradillas, Guajataca, P.R., July 4, 1951, taken by J. Maldonado Capriles.

\section{SUMMARY}

In this somewhat preliminary survey of the collembolan fauna of this region 10 additions have been made to the short list of species previously known to occur in Puerto Rico. Nine new species, two new genera, and two new subgenera are described. Three of these new forms are closely related to forms found in India and in Africa.

\section{RESUMEN}

En este reconocimiento preliminar de la fauna collenboliana de esta región, se han hecho 10 adiciones a la corta lista de especies que anteriormente se conocían en Puerto Rico. Nueve nuevas especies, dos nuevos géneros, y dos nuevos subgéneros se describen aquí. Tres de estas nuevas formas están relacionadas estrechamente con formas encontradas en India y Africa. 